\title{
HORMONAL REGULATION OF $\alpha$-AMYLASE INHIBITOR SYNTHESIS IN GERMINATING BARLEY
}

by

\author{
JOHN MUNDY
}

\begin{abstract}
Department of Biotechnology, Carlsberg Research Laboratory, Gamle Carlsberg Vej 10, DK-2500 Valby, Copenhagen, Denmark
\end{abstract}

Keywords: Abscisic acid, gibberellic acid, bifunctional $\alpha$-amylase/subtilisin inhibitor,
aleurone layer

The in vivo synthesis of $\alpha$-amylase and of a bifunctional inhibitor of endogenous $\alpha$-amylase and subtilisin was studied in embryoless barley half grains treated with abscisic (ABA) and gibberellic $\left(\mathrm{GA}_{3}\right)$ acids. Fluorography of newly synthesized proteins and of immunoprecipitated $\alpha$-amylase and its inhibitor separated by SDS-PAGE showed that $\mathrm{GA}_{3}$ induces the production of large amounts of $\alpha$-amylase while the synthesis of other proteins, including the $\alpha$-am ylase inhibitor, is reduced. In contrast, synthesis and/or accumulation of the inhibitor is induced in embryoless half seeds incubated with ABA. These results identify the $\alpha$-amylase inhibitor as an ABA-induced protein in barley aleurone layers and suggest that it functions as an active mediator of amylase activity during the development and germination of barley seeds.

\section{INTRODUCTION}

During grain development in barley, several albumin proteins are synthesized in the developing endosperm concomitant with the synthesis of large amounts of prolamin storage proteins $(10,16)$. One of these soluble seed proteins has recently been identified as an inhibitor of the endogenous barley $\alpha$-amylase 2 isozyme and of the bacterial protease subtilisin and has been shown by amino acid sequencing to be a member of the soybean trypsin inhibitor (Kunitz) family $(11,18,23,24)$. As with other seed proteins (2), the level of translatable mRNA for this bifunctional inhibitor peaks from 15 to 30 days after anthesis (MUNDY and BRANDT, unpublished data).
During germination, the de novo synthesis of $\alpha$-amylase, which metabolises the starch stored in the endosperm, can be enhanced in the aleurone layers by the plant hormone gibberellic acid $\left(\mathrm{GA}_{3}\right)(8,12)$. By comparing in vivo and in vitro translation products and by hydridization of $\alpha$-amylase cDNAs to total germinating barley mRNAs, it has been found that the increase in $\alpha$-amylase synthesis is due to $\mathrm{GA}_{3}$-stimulated transcription of genes encoding $\alpha$-amylase ( 1 , 20). The stimulation of transcription can be blocked by the addition of the plant hormone abscisic acid (ABA) to the tissue, and regulation of $\alpha$-amylase gene expression by ABA has been suggested to occur either at the transcriptional or

Abbreviations: $A B A=( \pm)$ cis-trans abscisic acid; $\mathrm{GA}_{3}=$ gibberellic acid $\mathrm{A}_{3} ;$ SDS-PAGE = sodium dodecyl sulfate - polyacrylamide gel electrophoresis 
at the translational level $(13,14,17,19)$. These studies have found that the synthesis of a number of functionally uncharacterized polypeptides of $M_{r} \sim 21,23,25,27,31$ and $36 \times 10^{3}$ is stimulated in barley aleurone layers by ABA. According to MUTHUKRISHNAN et al. (19) the synthesis of a polypeptide of $\mathrm{Mr} 16-21 \times 10^{3}$ is enhanced in aleurone layers by the lysine analogue S-2-aminoethyl-L-cysteine, itself an inhibitor of the transcription of the $\alpha$-amylase gene. In vitro translation products of $\mathrm{Mr} \sim 23,30$ and $74 \times 10^{3}$ are formed by mRNA isolated from layers treated with $\mathrm{ABA}$ (17).

The present study was undertaken to find out whether the synthesis of the inhibitor of $\alpha$-amylase $2(18,23)$ is hormonally controlled in aleurone layers of germinating barley. Towards this end, rabbit antibodies raised against $\alpha$-amylase 2 and its inhibitor have been used to probe the ${ }^{35} \mathrm{~S}$-labelled, newly synthesized polypeptides of embryoless half grains incubated for 8 and 16 hours with $\mathrm{ABA}$ and $\mathrm{GA}_{3}$.

\section{MATERIALS AND METHODS}

2.1. Isolation of $\alpha$-amylase 2 and its inhibitor and antibody production

The isolation of the major barley malt $\alpha$-amylase 2 isozyme from an extract of germinated barley (Hordeum vulgare L., cv. Nordal) by glycogen precipitation and $\beta$-cycloheptaamylose affinity chromatography and the production of antibodies towards this enzyme preparation have been previously described (7). The $\alpha$-amylase/subtilisin inhibitor was isolated from a similar barley extract by glycogen precipitation followed by CM-cellulose (Whatman CM-52) chromatography after (18). Rabbits were immunized with $150 \mu \mathrm{g}$ purified inhibitor $\times \mathrm{ml}^{-1}$ in 3 dorsal subcutaneous depots of $0.3 \mathrm{ml}$ and tapped after a standard immunization schedule (9). IgGs were purified from the crude antisera by chromatography on protein A-Sepharose 6B. The monospecificities of the IgG preparations were checked by SDS-PAGE of extracts of germinated barley half seeds followed by electrophoretic blotting of the proteins and immunological assay essentially as described in (21).
2.2. Labelling and analysis of proteins synthesized in quartered half seeds

Barley (Hordeum vulgare, L., cv. Nudinka) embryoless, half grains were surface sterilized with $0.2 \% \mathrm{AgNO}_{3}$ and imbibed for 3 days on sterile, wet sand. Samples of 20 half seeds were quartered and incubated in $20 \mathrm{ml}$ of solutions containing the hormones $(50 \mu \mathrm{M}-\mathrm{ABA}$ and 10 $\mu \mathrm{M}-\mathrm{GA}_{3}$, Sigma). These hormone concentrations have been found appropriate in an in vivo/in vitro study (17) and in a cytochemical study of $\alpha$-amylase synthesis in whole seeds (8). After 4 and 12 hours the seed portions were placed in fresh solutions. At 6 and 14 hours fresh solutions containing $30 \mu \mathrm{Ci}{ }^{35} \mathrm{~S}$-methionine (Amersham) were added, and the incubations continued for 2 hours. The seed portions were then rinsed in water, frozen in liquid nitrogen, and powdered in a mortar and pestle. The powders were extracted by shaking for $20 \mathrm{~min}$ at room temperature in $5 \mathrm{ml} 1 \mathrm{mM}-\mathrm{CaCl}_{2}$, centrifuged at $16,000 \times \mathrm{g}$ for $10 \mathrm{~min}$ and the supernatants lyophilized. The samples were dissolved in 50 mM-Tris-HCl, $\mathrm{pH} 7.5,0.15 \mathrm{M}-\mathrm{NaCl}, 2 \%$ Triton $\mathrm{X}-100$, and $10 \mathrm{mM}$-methionine, TCA precipitable counts measured, and aliquots containing equal radioactivity taken for analysis of total in vivo synthesized proteins and for sequential immunoprecipitation with $\alpha$-amylase antibodies followed by inhibitor antibodies as described in (15). Proteins were separated by SDSPAGE in a $12.5 \%$ gel according to (4) with a sample buffer of $0.2 \mathrm{M}$-Tris- $\mathrm{HCl}, \mathrm{pH} 8.8,0.5$ M-sucrose, $0.01 \%$ Bromphenol blue, $5 \mathrm{~mm}$-NaEDTA, 1\% methionine, 4\% SDS, 10 mM-DTT, and $10 \mathrm{~mm}$-iodoacetamide. Gels were prepared for fluorography after (3) and exposed to RP Royal X-omat film (Kodak) at $-70{ }^{\circ} \mathrm{C}$ for 60 days, and then developed.

\section{RESULTS}

3.1. Specificities of the antibody preparations

The monospecificity of the $\alpha$-amylase/subtilisin inhibitor antibody preparation is revealed by the immune-blotting test presented in Figure 1. It appears that the $\alpha$-amylase 2 antibody preparation contains low amounts of antibodies towards the inhibitor, a contamination which is due to the co-elution of small quantities of 


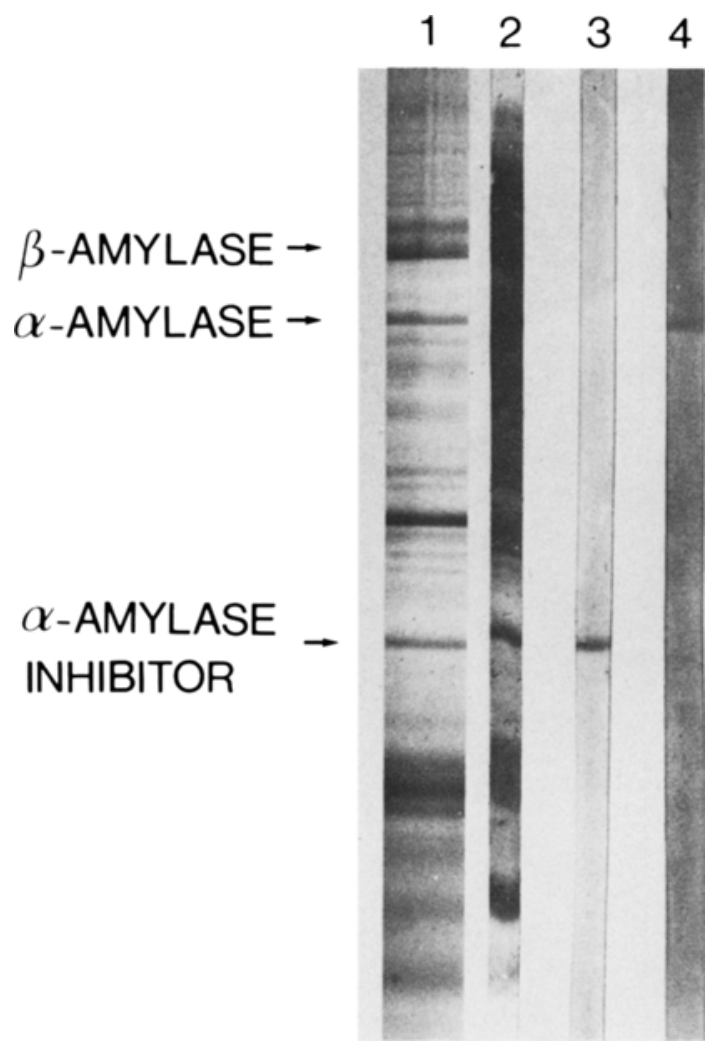

Figure 1. Immune-blotting assay of proteins in embryoless barley half grains after separation by SDSPAGE Lanes: 1, proteins in germinated barley half seeds were extracted with sample buffer, separated by SDS-PAGE and stained with Coomassie brilliant blue R-250; 2, proteins transferred electrophoretically in $0.15 \mathrm{M}$-Tris-glycine buffer ( $\mathrm{pH} 8.9$ ), $20 \%$ methanol to nitrocellulose paper (Millipore type HAHY) and stained with amido black; 3 and 4 , nitrocellulose strips incubated with $0.2 \mathrm{mg} \times \mathrm{ml}^{-1}$ rabbit antibodies raised against the $\alpha$-amylase inhibitor and $\alpha$-amylase, respectively, assayed with peroxidase-labelled swine anti-rabbit antibodies.

inhibitor-enzyme complexes with free $\alpha$-amylase from the $\beta$-cycloheptaamylose affinity column (18).

\subsection{Newly synthesized proteins in embryoless half grains}

The fluorograph of total proteins synthesized by portions of embryoless half grains after a 16 hours incubation (Figure 2, lanes 1-4) shows patterns similar to those observed by others (14, 17). In $\mathrm{GA}_{3}$ treated tissue (lane 3 ), the increase in the synthesis of $\alpha$-amylase $\left(M_{r} \sim 42 \times 10^{3}\right)$ is accompanied by a decrease in the number of other newly synthesized polypeptides. In ABAtreated tissue (lanes 2 and 4) synthesis of $\alpha$-amylase is markedly decreased while the synthesis of polypeptides with an $\mathrm{M}_{\mathrm{r}} \sim 14,20,25,28,31,35$ and $50 \times 10^{3}$ appears to be increased compared to both the control and $\mathrm{GA}_{3}$ treatments (lanes 1 and 3 ). The fluorograph of polypeptides synthesized after 8 hours revealed similar patterns. Especially the synthesis of polypeptides of $M_{r} \sim 14,20,27$ and $35 \times 10^{3}$ appeared to be stimulated by ABA. The amount of $\alpha$-amylase was not as pronounced at 8 hours as at 16 hours, presumably because the amount of translatable mRNA for $\alpha$-amylase first reaches a maximum after 10 hours of incubation (14).

\subsection{Immunoprecipitation of proteins synthe- sized in embryoless half grains}

Since the embryo and scutellum has been removed prior to incubation of the half grains, it is likely that the synthesis of the proteins studied takes place in the aleurone layers. As judged by the amount of immunoprecipitates, the synthesis of $\alpha$-amylase is the same upon incubation in the absence and presence of both $\mathrm{ABA}$ and $\mathrm{GA}_{3}$ (Figure 2, lanes 5 and 8). The strong enhancement of $\alpha$-amylase synthesis by $\mathrm{GA}_{3}$ and its inhibition by ABA illustrated in lanes 6 and 7 is in agreement with previous work $(14,17)$, indicating that the conditions employed in the present experiment are comparable.

Immunoprecipitation with antibodies to the inhibitor shows that very small amounts of inhibitor $\left(M_{r} \sim 20,500\right)$ are synthesized in aleurone layers in the absence of the hormones (lane 9). The regulation of synthesis of this polypeptide is the reverse of that for $\alpha$-amylase; synthesis and/or accumulation of the inhibitor is induced by $\mathrm{ABA}$ and inhibited by $\mathrm{GA}_{3}$ (lanes 10 and 11 ). The induction of the synthesis of the inhibitor by ABA does not appear to be strongly affected by the presence of $\mathrm{GA}_{3}$ in the medium at the levels used in this experiment (lane 12). It should be noted that the apparent co-precipitation of $\alpha$ - 
the inhibitor, to an increase in the translational efficiency of pre-existing inhibitor mRNAs or to a reduction in turnover of newly synthesized inhibitor molecules. Synthesis of the inhibitor does not occur in embryoless half seeds treated with $\mathrm{GA}_{3}$, a finding in keeping with the conclusions of others that $\mathrm{GA}_{3}$ redirects overall transcription to produce large amounts of mRNA coding for $\alpha$-amylase and a few other polypeptides in the aleurone layers.

The fact that the barley $\alpha$-amylase/subtilisin inhibitor is synthesized as a seed protein during endosperm development and that its synthesis can be induced in germinating seeds by $A B A$ suggests that it may function in the prevention of precocious germination. Polypeptides normally synthesized during embryogenesis whose synthesis can be induced by $\mathrm{ABA}$ during germination have been described in cotton seeds (6) and it will be interesting to study if some of these cotton proteins are hydrolase inhibitors.

Although it is possible that the barley inhibitor is synthesized to inhibit the activity of precociously made $\alpha$-amylase activity in developing seeds, it could also represent one of many seed proteins controlled by ABA. Work on storage protein synthesis in embryos of Brassica napus points to such a broad response of developing seed tissues to ABA (5). Further work is therefore needed to determine 1) the physiological role of the bifunctional barley inhibitor in regulating amylolytic activity during development and germination, and (2) the molecular mechanism by which $\mathrm{ABA}$ induces inhibitor synthesis and/or accumulation.

\section{ACKNOWLEDGEMENTS}

The author wishes to thank LARS MUNCK and GREGORY GIBBONS, Department of Biotechnology, Carlsberg Research Laboratory, for their support of this work and for the use of the $\alpha$-amylase antibodies, and ANDERS BRANDT and Gunilla HøYeR-HANSEN, Department of Physiology, Carlsberg Laboratory, for their expert advice. Professor D. von WeTtSTEIN is thanked for his critical review of the manuscript and ANETTE HANSEN is thanked for preparing the figures.

\section{REFERENCES}

1. Bernal-Lugo, I., R. Beachy \& J. Varner: The response of barley aleurone layers to gibberellic acid includes the transcription of new sequences. Biochem. Biophys. Res. Commun. 102, 617-623 (1981)

2. BRANDT, A.\& J. INGVERSEN: Isolation and translation of hordein messenger RNA from wild type and mutant endosperms in barley. Carlsberg Res. Commun. 43, 451-469 (1978)

3. Chamberlain, J.P.: Fluorographic detection of radioactivity in polyacrylamide gels with the water-soluble fluor, sodium salicylate. Anal. Biochem. 98, 132-135 (1979)

4. Chua, N.-H. \& P. Bennoun: Thylakoid membrane polypeptides of chlamydomonas reinhardtii: Wild-type and mutant strains deficient in photosystem II reaction center. Proc. Nat. Acad. Sci. 72, 2175-2179 (1975)

5. Crouch, M.L. \& I.M. Sussex: Development and storage-protein synthesis in Brassica napus L. embryos in vivo and in vitro. Planta 153, 64-74 (1981)

6. Dure, L., S.C. Greenway \& G.A. Galau: Developmental biochemistry of cottonseed embryogenesis and germination: Changing messenger ribonucleic acid populations as shown by in vitro and in vivo protein synthesis. Biochemistry. $20,4162-$ 4168 (1981)

7. Gibbons, G.C.: On the localisation and transport of $\alpha$-amylase during germination and early seedling growth of Hordeum vulgare. Carlsberg Res. Commun. 44, 353-366 (1979)

8. Gibbons, G.C.: On the relative role of the scutellum and aleurone in the production of hydrolase during germination of barley. Carlsberg Res. Commun. 46, 215-225 (1981)

9. HARBOE, N. \& A. INGILD: Immunization, isolation of immunoglobulins and estimation of antibody titre:, in A manual of quantitative immunoelectrophoresis, eds, Axelsen, N., Krøll, J. \& Weeke, B. (University Press, Oslo, Norway) pp. 161-164 (1973)

10. HejgaARd, J.\& S. Boisen: High-lysine proteins in Hiproly barley breeding: Identification, nutritional significance and new screening methods. Hereditas 93, 311-320 (1980)

11. HejgaArd, J., I. Svendsen \& J. Mundy: Barley $\alpha$-amylase/subtilisin inhibitor. II. N-terminal amino acid sequence and homology with inhibitors of the soybean trypsin inhibitor (Kunitz) family. Carlsberg Res. Commun. 48, 91-94 (1983)

12. Higgins, T.J.V., J.A. ZwaR \& J.V. JaCOBSEN: Gibberellic acid enhances the level of translatable mRNA for $\alpha$-amylase in barley aleurone layers. Nature 260, 166-168 (1976) 
13. HIGGINS, T.J.V., J.V. JACOBSEN \& J.A ZWAR: Gibberellic acid and abscisic acid modulate protein synthesis and mRNA levels in barley aleurone layers. Plant Molec. Biol. 1, 191-215 (1982)

14. Ho, D.T.H. \& J.E. VARNER: Response of barley aleurone layers to abscisic acid. Plant Physiol. 57, 175-178 (1976)

15. Jonassen, I., J. Ingversen \& A. Brandt: Synthesis of SP II albumin, $\alpha$-amylase and chymotrypsin inhibitor $\mathrm{Cl}-1$ on polysomes from the endoplasmic reticulum of barley endosperm. Carlsberg Res. Commun. 46, 175-181 (1981)

16. KIRSI, M.: Formation of proteinase inhibitors in developing barley grains. Physiol. Plant. 29, 141144 (1973)

17. Mozer, T J.: Control of protein synthesis in barley aleurone layers by the plant hormones gibberellic acid and abscisic acid. Cell 20, 479-485. (1980)

18. Mundy, J., I. Svendsen \& J. HejgaArd: Barley $\alpha$-amylase/subtilisin inhibitor. I. Isolation and characterization. Carlsberg Res. Commun. 48, $81-90$ (1983)
19. Muthukrishnan. S., G.R. Chandra \& G.P. ALBAUGH: Modulation by abscisic acid and S-2-aminoethyl-L-cysteine of $\alpha$-amylase mRNA in barley aleurone cells. Plant Mol. Biol. 2, 249-258 (1983)

20. Muthukrishnan, S.,G.R.Chandra \& E.S.MaXWELL: Hormonal control of $\alpha$-amylase gene expression in barley. J. Biol. Chem. 258, 2370-2375 (1983)

21. TOWBin, H., T. Staehelin \& J. Gordon: Electrophoretic transfer of proteins from polyacrylamide gels to nitrocellulose sheets: Procedure and some applications. Proc. Natl. Acad. Sci. 76, 4350-4354 (1979)

22. WaLton, D.C.: Abscisic acid and seed germination. Annu. Rev. Plant Physiol. 31, 453-489(1980)

23. Weselake, R.J., A.W. MacGregor \& R.D. Hill: An endogenous $\alpha$-amylase inhibitor in barley kernels. Plant Physiol. 72, 809-812 (1983)

24. Weselake, R.J., A.W. MaC-GRegor, R.D. Hill \& H.W. DUCKWORTH: Purification and characteristics of an endogenous $\alpha$-amylase inhibitor from barley kernels. Plant Phys. 73, 1008-1012 (1983) 